\title{
Solution/Ammonolysis Syntheses of Unsupported and Silica-Supported Copper(I) Nitride Nanostructures from Oxidic Precursors
}

\author{
Robert Szczęsny ${ }^{1,2, *(\mathbb{D})}$, Tuan K. A. Hoang ${ }^{1,3}$, Liliana Dobrzańska ${ }^{2} \mathbb{D}$ and Duncan H. Gregory ${ }^{1, *(D)}$ \\ 1 WestCHEM, School of Chemistry, University of Glasgow, Glasgow G12 8QQ, UK; \\ Hoang.Tuan@hydroquebec.com \\ 2 Faculty of Chemistry, Nicolaus Copernicus University in Toruń, Gagarina 7, 87-100 Toruń, Poland; \\ lianger@umk.pl \\ 3 Hydro-Québec Research Institute, Hydro-Québec, 1806, Boul. Lionel-Boulet, Varennes, QC J3X 1S1, Canada \\ * Correspondence: Robert.Szczesny@umk.pl (R.S.); Duncan.Gregory@Glasgow.ac.uk (D.H.G.)
}

Citation: Szczęsny, R.; Hoang, T.K.A.; Dobrzańska, L.; Gregory, D.H. Solution/Ammonolysis Syntheses of Unsupported and Silica-Supported Copper(I) Nitride Nanostructures from Oxidic Precursors. Molecules 2021, 26, 4926. https://doi.org/ 10.3390/molecules26164926

Academic Editor: Myung-Hwan Whangbo

Received: 6 July 2021

Accepted: 11 August 2021

Published: 14 August 2021

Publisher's Note: MDPI stays neutral with regard to jurisdictional claims in published maps and institutional affiliations.

Copyright: () 2021 by the authors. Licensee MDPI, Basel, Switzerland. This article is an open access article distributed under the terms and conditions of the Creative Commons Attribution (CC BY) license (https:// creativecommons.org/licenses/by/ $4.0 /)$.

\begin{abstract}
Herein we describe an alternative strategy to achieve the preparation of nanoscale $\mathrm{Cu}_{3} \mathrm{~N}$. Copper(II) oxide/hydroxide nanopowder precursors were successfully fabricated by solution methods. Ammonolysis of the oxidic precursors can be achieved essentially pseudomorphically to produce either unsupported or supported nanoparticles of the nitride. Hence, $\mathrm{Cu}_{3} \mathrm{~N}$ particles with diverse morphologies were synthesized from oxygen-containing precursors in two-step processes combining solvothermal and solid-gas ammonolysis stages. The single-phase hydroxochloride precursor, $\mathrm{Cu}_{2}(\mathrm{OH})_{3} \mathrm{Cl}$ was prepared by solution-state synthesis from $\mathrm{CuCl}_{2} \cdot 2 \mathrm{H}_{2} \mathrm{O}$ and urea, crystallising with the atacamite structure. Alternative precursors, $\mathrm{CuO}$ and $\mathrm{Cu}(\mathrm{OH})_{2}$, were obtained after subsequent treatment of $\mathrm{Cu}_{2}(\mathrm{OH})_{3} \mathrm{Cl}$ with $\mathrm{NaOH}$ solution. $\mathrm{Cu}_{3} \mathrm{~N}$, in the form of micro- and nanorods, was the sole product formed from ammonolysis using either $\mathrm{CuO}$ or $\mathrm{Cu}(\mathrm{OH})_{2}$. Conversely, the ammonolysis of dicopper trihydroxide chloride resulted in two-phase mixtures of $\mathrm{Cu}_{3} \mathrm{~N}$ and the monoamine, $\mathrm{Cu}\left(\mathrm{NH}_{3}\right) \mathrm{Cl}$ under similar experimental conditions. Importantly, this pathway is applicable to afford composite materials by incorporating substrates or matrices that are resistant to ammoniation at relatively low temperatures (ca. $300{ }^{\circ} \mathrm{C}$ ). We present preliminary evidence that $\mathrm{Cu}_{3} \mathrm{~N} / \mathrm{SiO}_{2}$ nanocomposites (up to ca. $5 \mathrm{wt}$. $\% \mathrm{Cu}_{3} \mathrm{~N}$ supported on $\mathrm{SiO}_{2}$ ) could be prepared from $\mathrm{CuCl}_{2} \cdot 2 \mathrm{H}_{2} \mathrm{O}$ and urea starting materials following similar reaction steps. Evidence suggests that in this case $\mathrm{Cu}_{3} \mathrm{~N}$ nanoparticles are confined within the porous $\mathrm{SiO}_{2}$ matrix.
\end{abstract}

Keywords: copper nitride; ammonolysis reaction; urea; $\mathrm{CuO} ; \mathrm{Cu}(\mathrm{OH})_{2} ; \mathrm{Cu}_{2}(\mathrm{OH})_{3} \mathrm{Cl}$

\section{Introduction}

Copper nitride is nontoxic and relatively stable at ambient conditions. It is a semiconductor with high electrical resistivity, low reflectivity, and low thermal stability [1-3]. With regard to its potential commercial value and interesting properties, $\mathrm{Cu}_{3} \mathrm{~N}$ has been exploited for applications in optical storage media [4-8], as a component of spintronic systems [9,10], as an electrode material in rechargeable Li- and Na-ion batteries [11-14] and as a highly active catalyst [15-19]. More specifically, thin films of $\mathrm{Cu}_{3} \mathrm{~N}$ can be utilized in the fabrication of microscopic metal lines, dots, or $\mathrm{Cu} / \mathrm{Cu}_{3} \mathrm{~N}$ microscopic structures using electron beam or laser irradiation [7,20-24]. These processes can be implemented effectively by exploiting the inherent thermal instability of copper nitride. Thermal treatment at a moderate temperature decomposes $\mathrm{Cu}_{3} \mathrm{~N}$ into nitrogen and pure metallic copper and the deposited $\mathrm{Cu}$ metal unsurprisingly has a significantly higher reflectivity and conductivity than its nitride. Otherwise, the magnetic properties of $\mathrm{Cu}_{3} \mathrm{~N}$ offer applicability in devices as spin valves [7] or can be exploited to examine the spin excitations of antiferromagnetic $\mathrm{Mn}$ chains [6]. $\mathrm{Cu}_{3} \mathrm{~N}$ forms a cubic anti- $\mathrm{ReO}_{3}$ type structure (space group $\mathrm{Pm}-3 \mathrm{~m}$ ) where 
nitrogen atoms are located at the corners of the primitive unit cell and copper atoms occupy the $3 d$ edge sites. Given the open nature of the structure, in some circumstances, it is possible to insert metal atoms into the interstitial body centre $(1 / 2,1 / 2,1 / 2)$ position $[25,26]$. According to previous studies, the addition of a transition metal modifies not only the electronic properties of $\mathrm{Cu}_{3} \mathrm{~N}$ but also its magnetic characteristics and, for example, provides a route to magnetic semiconductors [3,27].

Whereas films of copper nitride have primarily been fabricated by physical methods such as reactive RF magnetron sputtering [28-30] or pulsed laser deposition (PLD) [31,32], bulk $\mathrm{Cu}_{3} \mathrm{~N}$ was first synthesized by Juza and Rabenau many decades before by heating a $\mathrm{CuF}_{2}$ precursor under gaseous ammonia [33]. The same precursor was utilized by Gregory et al. to prepare gram quantities of copper nitride for powder neutron diffraction studies [34]. A contrasting approach was taken by Zachwieja and Jacobs in 1990 who used nitrate amine "single source" precursors, $\left[\mathrm{Cu}\left(\mathrm{NH}_{3}\right) \mathrm{x}\right] \mathrm{NO}_{3}(2 \leq \mathrm{x} \leq 3)$ to prepare $\mathrm{Cu}_{3} \mathrm{~N}$ without the need for ammonia, via a direct thermal decomposition reaction [35]. More recently, however, there has been added interest in the synthesis of different types of $\mathrm{Cu}_{3} \mathrm{~N}$ nanostructures [36,37]. A flurry of different synthesis routes was applied to synthesise nitride nanoparticles, for example by solvothermal methods using copper azide in toluene or THF at moderate temperature [38], by thermal decomposition of $\mathrm{Cu}\left(\mathrm{NO}_{3}\right)_{2}$ in solutions containing long chain amines as solvents and capping agents [39-41], via the reaction of copper(II) acetate with $\mathrm{NH}_{3}$ gas in long-chain alcohol solvents [42] by a one-step process in which copper(II) methoxide reacts with benzylamine [43] or by reduction of $\mathrm{Cu}$ (II) to $\mathrm{Cu}(\mathrm{I})$ combined with nitridation of $\mathrm{Cu}(\mathrm{I})$ by hexamethylenetetramine [44].

Urea $\left(\mathrm{CO}\left(\mathrm{NH}_{2}\right)_{2}\right)$ has also been investigated as an alternative-nongaseous-nitrogen source to $\mathrm{NH}_{3}$ [45]. In this work, we utilized $\mathrm{CO}\left(\mathrm{NH}_{2}\right)_{2}$ for $\mathrm{Cu}_{3} \mathrm{~N}$ fabrication in a twostep process. Urea is soluble in water and its well-known hydrolysis process results in ammonia and carbon dioxide evolution. The thermally induced decomposition of urea in solution causes a relatively slow increase in $\mathrm{pH}$ which can be utilized to fabricate nanoparticles [46]. Urea can also play the role of capping and reducing agent in the synthesis of nanoparticles [47]. Moreover, utilizing $\mathrm{CO}\left(\mathrm{NH}_{2}\right)_{2}$ combined with ethylene glycol (EG) can improve the uniformity of the dispersed precipitate [48].

Generally, the development of facile, inexpensive synthetic methods is especially valuable given the emerging commercial applications of nanomaterials. Synthesis using long-chain amines [39-41] is becoming the most-utilized chemical method for the fabrication of $\mathrm{Cu}_{3} \mathrm{~N}$ nanopowders. Implementing this route on a commercial basis is challenging, however, due both to the costs of the required chemicals and to the limits of morphological control that can be exerted [40]. In our approach, we propose important modifications to the classical approach to late transition metal nitride synthesis; namely the reaction of a suitable precursor in gaseous ammonia. Importantly, ammonolysis does not change the initial shape of the nanoparticles and so by using prescribed precursor morphologies, it is possible to exert intricate control over the copper nitride nanostructure. Moreover, ammonolysis can be applied to composite materials including substrates or matrices that are resistant to interaction with $\mathrm{NH}_{3}$ at temperatures of approximately $300{ }^{\circ} \mathrm{C}$ or less. We reveal experimental results here that demonstrate that exploiting oxygen-containing inorganic precursors, such as $\mathrm{CuO}$ and $\mathrm{Cu}(\mathrm{OH})_{2}$ in ammonolysis reactions, leads to the formation of single-phase $\mathrm{Cu}_{3} \mathrm{~N}$ under a range of experimental conditions. Furthermore, $\mathrm{Cu}_{3} \mathrm{~N}$ composites can be produced in the same way. A range of such experiments illustrates the diversity of $\mathrm{Cu}_{3} \mathrm{~N}$-based nanomaterials that can be fabricated by this precise two-step approach. In each case, the desired morphology is prescribed by the precursor design in step 1. Simple heating in ammonia then yields $\mathrm{Cu}_{3} \mathrm{~N}$ pseudomorphically in step 2.

In this paper, as an example of this approach, copper(II) chloride dihydrate was used as a precursor for the fabrication of copper(II) oxide and copper(II) hydroxide nanoarchitectures (via synthesis of the hydroxide chloride, $\mathrm{Cu}_{2}(\mathrm{OH})_{3} \mathrm{Cl}$ ). The preparation of copper nitride micro- and nanostructures was then realized by ammonolysing the $\mathrm{Cu}(\mathrm{OH})_{2}$ and $\mathrm{CuO}$ nanoparticle precursors. $\mathrm{Cu}_{3} \mathrm{~N} / \mathrm{SiO}_{2}$ nanocomposites comprising $\mathrm{Cu}_{3} \mathrm{~N}$ nanoparti- 
cles supported on silica could be assembled using the same precursors in closely related protocols. This is the first time that systematic studies of supported and unsupported $\mathrm{Cu}_{3} \mathrm{~N}$ nanostructures synthesized by this method have been performed. As we demonstrate, the synthetic method can be applied to the growth of different shapes and sizes of nanocrystalline copper nitride, which, despite evidence of negligible porosity when unsupported, can nevertheless display specific surface areas of up to $45 \mathrm{~m}^{2} \mathrm{~g}^{-1}$.

\section{Results and Discussion}

\subsection{Synthesis and Ammonolysis Reactions}

In a typical synthesis, copper(II) chloride $\mathrm{CuCl}_{2} \cdot 2 \mathrm{H}_{2} \mathrm{O}(3 \mathrm{mmol})$ was dissolved in a water/EG mixture $\left(28 \mathrm{~cm}^{3} ; v / v, 1: 8.3\right)$ in a round-bottomed flask to which $\mathrm{CO}\left(\mathrm{NH}_{2}\right)_{2}$ $(17 \mathrm{mmol})$ was added with constant stirring. The resultant light green solution was heated to $95{ }^{\circ} \mathrm{C}$ over a period of $1.5-2.5 \mathrm{~h}$. During the reaction, a green precipitate of $\mathrm{Cu}_{2}(\mathrm{OH})_{3} \mathrm{Cl}$ formed from a deep blue solution. The final solid product was collected by centrifuging and was washed with water and alcohol several times before dispersing in acetone. A jade-green precipitate of $\mathrm{Cu}_{2}(\mathrm{OH})_{3} \mathrm{Cl}$ was obtained from the remaining deep navy blue solution after leaving to stand at ambient temperature in air for several days.

To prepare $\mathrm{CuO}$ powder, a $0.01 \mathrm{M}$ solution of $\mathrm{NaOH}$ was added dropwise into the previously described green $\mathrm{Cu}_{2}(\mathrm{OH})_{3} \mathrm{Cl}$ powders dispersed in $\mathrm{EtOH}$ with constant stirring until a black precipitate formed. A very similar method was used to prepare $\mathrm{Cu}(\mathrm{OH})_{2}$ powder, with the exception that a few drops of $\mathrm{NH}_{3}(a q)$ were added to the $\mathrm{Cu} 2 \mathrm{Cl}(\mathrm{OH})_{3}$ water dispersion prior to adding the $0.01 \mathrm{M} \mathrm{NaOH}$ solution. Both the oxide and hydroxide products were centrifuged, washed and then dispersed in acetone. The synthesis route is shown schematically in Figure 1.

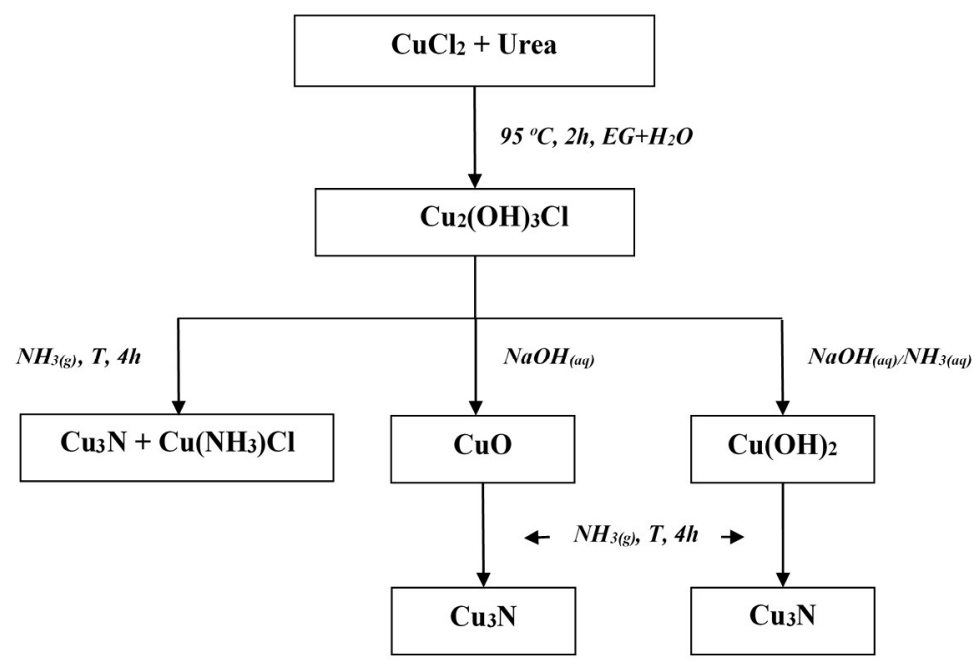

Figure 1. Schematic representation of the preparation processes for the respective powders.

As-received $\mathrm{SiO}_{2}$ aerogel is highly hydrophilic, with multiple -OH groups on the surface. The treatment of initial $\mathrm{SiO}_{2}$ with trimethylsilyl chloride was done as described in literature to completely remove the hydrophilicity on the surface [49-51]. The $\mathrm{Cu} 3 \mathrm{~N} / \mathrm{SiO}_{2}$ composite preparation procedure was similarly congruent to the synthesis of the unsupported $\mathrm{Cu}_{3} \mathrm{~N}$ nanoparticles by $\mathrm{Cu}(\mathrm{OH})_{2}$ powder and resulted in a final $\mathrm{Cu}_{3} \mathrm{~N}$ loading of 3.3 or 5.4 wt. \% on the $\mathrm{SiO}_{2}$ support. The $\mathrm{Cu}$ : urea molar ratio used in this process was 1:5. For a lower final load, the mixture of the $\mathrm{CuCl}_{2} \cdot 2 \mathrm{H}_{2} \mathrm{O}$ salt, urea and $\mathrm{SiO}_{2}$ in $\mathrm{H}_{2} \mathrm{O}$ was stirred for $2 \mathrm{~h}$ at room temperature before heating. A few drops of $0.5 \mathrm{M} \mathrm{NH}_{3}(a q)$ were then added prior to adding $\mathrm{NaOH}$ dropwise until a blue solution was obtained. The resulting suspension was centrifuged, washed with deionized water and acetone before dispersing in acetone. 
The ammonolysis experiments were performed in a horizontal tube furnace using $\mathrm{NH}_{3}$ gas (BOC, $99.98 \%$ ) as the nitriding agent. In each reaction, the dry precursor powder was placed in a ceramic boat $(60 \mathrm{~mm} \times 20 \mathrm{~mm} \times 20 \mathrm{~mm})$ and transferred to the centre of the furnace. Reaction temperatures between $240-310{ }^{\circ} \mathrm{C}$ were selected (see below) and in all cases, the maximum temperatures were reached in $\sim 45 \mathrm{~min}$. The furnace was allowed to cool naturally under flowing $\mathrm{NH}_{3}$.

\subsection{Characterization and Ammonolysis Reaction of Copper(II) Hydroxide Chloride Nanoparticles}

In the first step of our investigation, simple copper chloride nanoparticles were synthesized under various conditions. A SEM image of the powders obtained with $\mathrm{CuCl}_{2} \cdot \mathrm{H}_{2} \mathrm{O} / \mathrm{CO}\left(\mathrm{NH}_{2}\right)_{2}$ and $\mathrm{GE} / \mathrm{H}_{2} \mathrm{O}$ molar ratios of 1:6 and 8.3:1 respectively (A) is presented in Figure 2a. In the case of $\mathbf{A}$, a fine powder was obtained. The morphology and composition of the products were not affected by the gaseous environment (air or argon) in which the reactions were performed. SEM images for powder $\mathbf{B}$ fabricated under different conditions (using $\mathrm{CuCl}_{2} \cdot \mathrm{H}_{2} \mathrm{O} / \mathrm{CO}\left(\mathrm{NH}_{2}\right)_{2}$ and $\mathrm{GE} / \mathrm{H}_{2} \mathrm{O}$ molar ratios of 1:5 and 6.7:1, respectively) revealed that the prepared particles take a cubic form with dimensions of ca. $300-500 \mathrm{~nm}$ across (Figure $2 \mathrm{~b}$ ).
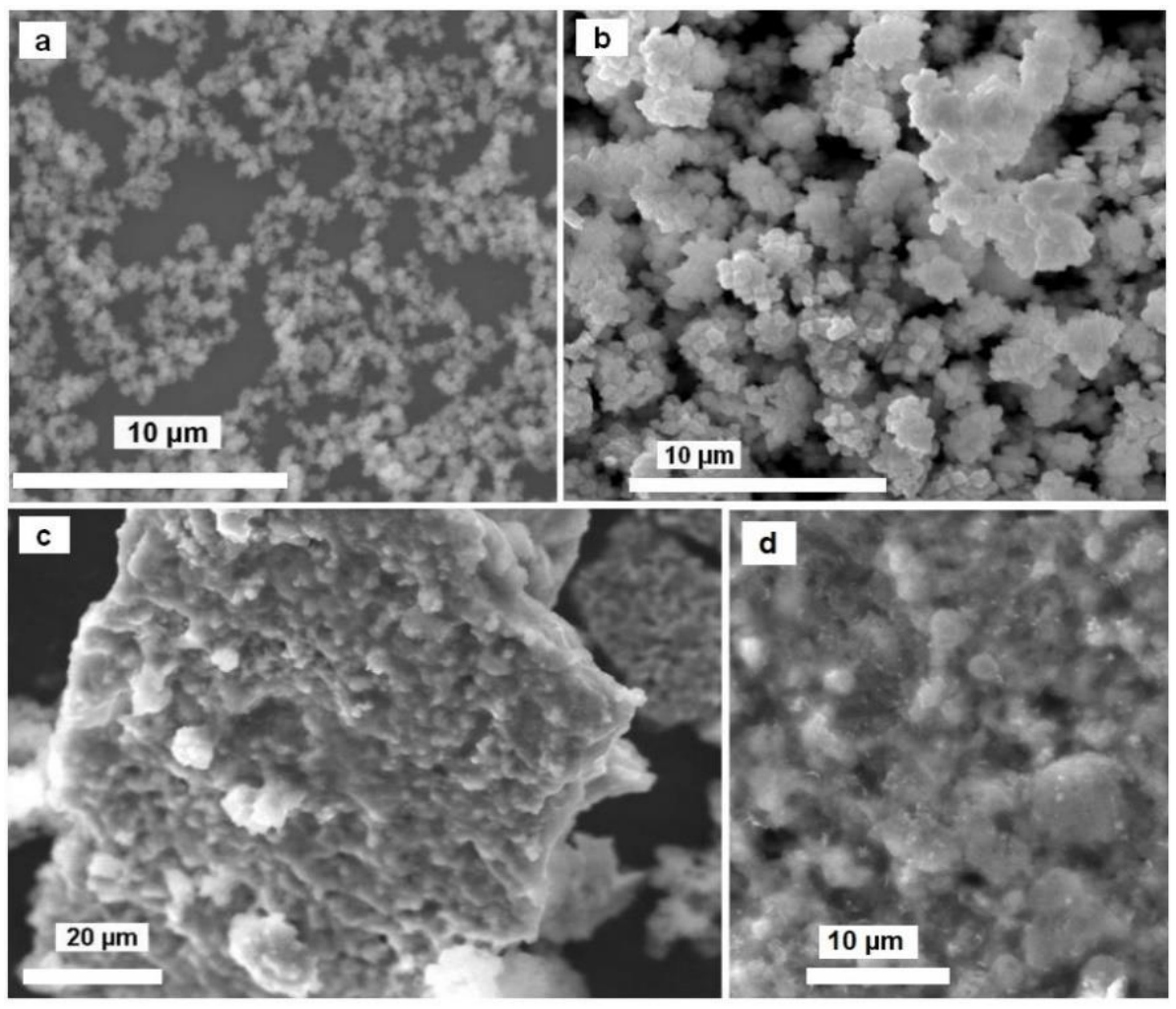

Figure 2. SEM images of as-prepared precursor powders: (a) sample A, (b) sample $\mathbf{B}$ and (c,d) sample A after ammonolysis reaction $\left(4 \mathrm{~h}, 300^{\circ} \mathrm{C}\right.$ sample $\left.\mathbf{1 b}\right)$.

The cubes form large spatial systems. Results from PXD and FT-IR experiments for the as-prepared samples (A and $\mathbf{B}$ ) indicated the presence of $\mathrm{Cu}_{2}(\mathrm{OH})_{3} \mathrm{Cl}$. According to the literature, natural copper(II) hydroxide chloride, $\mathrm{Cu}_{2}(\mathrm{OH})_{3} \mathrm{Cl}$, exists in nature in four different mineral phases: atacamite, botallackite, paratacamite, and clinoatacamite $[52,53]$. Figure 3a shows a PXD pattern of the formed product (sample A). All the diffraction peaks could be indexed according to the orthorhombic atacamite structure. For A, indexing yielded a unit cell in the space group Pnma with lattice parameters of $a=6.030(2) \AA$, $b=9.120(2) \AA, c=6.865(2) \AA$, which are in good agreement with the reported literature values [54]. 


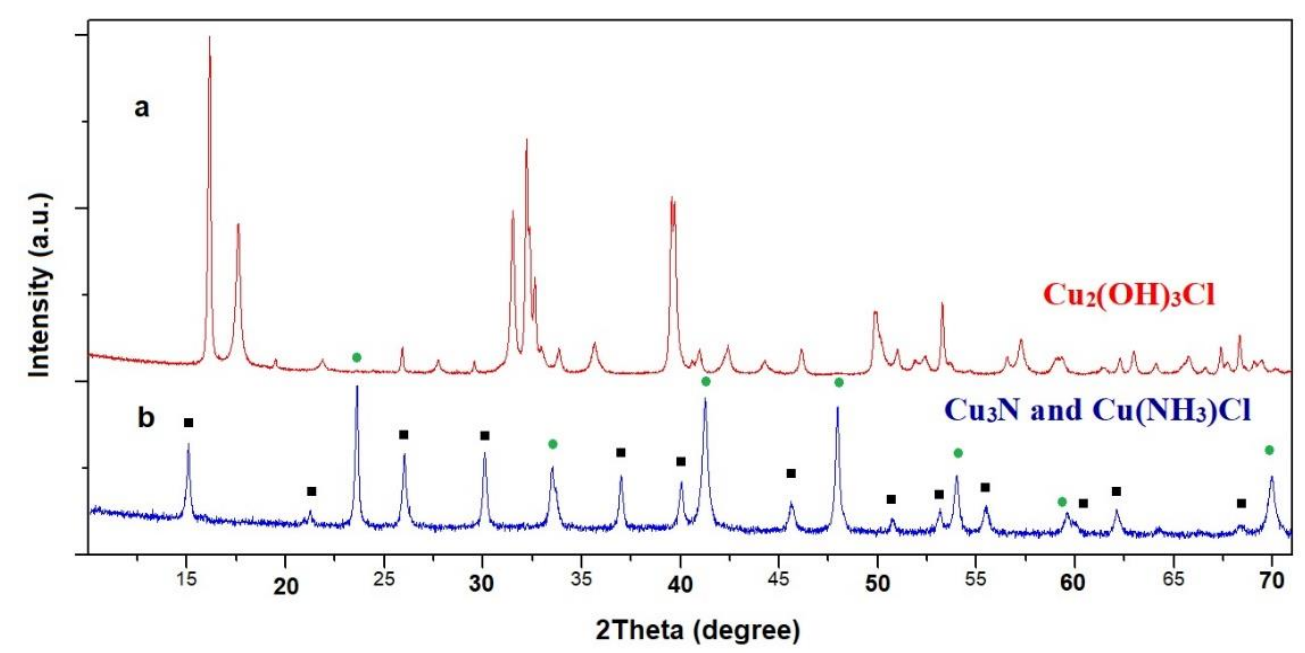

Figure 3. PXD patterns of (a) sample $\mathbf{A}$ as prepared and (b) sample $\mathbf{A}$ after heating in $\mathrm{NH}_{3}$ atmosphere at $300{ }^{\circ} \mathrm{C}(\mathbf{1 b})$. Sample $\mathbf{A}$ could be indexed as single-phase atacamite, while peaks in the pattern from sample $\mathbf{1 b}$ could be identified as $\mathrm{Cu}_{3} \mathrm{~N}(\boldsymbol{\square})$ and $\mathrm{Cu}\left(\mathrm{NH}_{3}\right) \mathrm{Cl}(\bullet)$.

The solution synthesis of $\mathrm{Cu}_{2}(\mathrm{OH})_{3} \mathrm{Cl}$ powders has been previously described using $\mathrm{NaOH} / \mathrm{H}_{2} \mathrm{O}_{2}$ [55], $\left(\mathrm{NH}_{4}\right)_{2} \mathrm{CO}_{3}$ [56] or $\mathrm{CO}\left(\mathrm{NH}_{2}\right)_{2}$ [57]. In the last of these alternatives, the formation of $\mathrm{Cu}_{2}(\mathrm{OH})_{3} \mathrm{Cl}$ from the hydrothermal reaction of copper(II) chloride and urea involves a hydrolysis-precipitation process. Urea is unstable under heating in aqueous solution and slowly liberates $\mathrm{OH}^{-}$which reacts with $\mathrm{Cu}^{2+}$ and $\mathrm{Cl}^{-}$in the reaction vessel to yield a green precipitate according to reactions:

$$
\begin{gathered}
\mathrm{CO}\left(\mathrm{NH}_{2}\right)_{2}+3 \mathrm{H}_{2} \mathrm{O} \rightarrow 2 \mathrm{OH}^{-}+2 \mathrm{NH}_{4}^{+}+\mathrm{CO}_{2}, \\
2 \mathrm{Cu}^{2+}+3 \mathrm{OH}^{-}+\mathrm{Cl}^{-} \rightarrow \mathrm{Cu}_{2}(\mathrm{OH})_{3} \mathrm{Cl} .
\end{gathered}
$$

Ammonolysis experiments using $\mathbf{A}$ as a precursor were performed at three different reaction temperatures $\left(240,300\right.$ and $\left.330{ }^{\circ} \mathrm{C}\right)$ for $4 \mathrm{~h}$. The SEM images of the products heated under $\mathrm{NH}_{3}$ reveal that the initial particle shape was not completely preserved, with clusters of nanoparticles aggregating to form semiporous "cake-like" structures (Figure 2c). For each reaction temperature used, the composition of the product was identical and according to PXD data, a two-phase product consisting of $\mathrm{Cu}_{3} \mathrm{~N}$ and $\mathrm{Cu}\left(\mathrm{NH}_{3}\right) \mathrm{Cl}$ (Figure $3 b$ ) was obtained [58]. Phase fractions ( $\mathrm{wt} \%$ ) were estimated using profile fitting within the PowderCell software package [59] and, as an example, a sample heated at $330^{\circ} \mathrm{C}$ contained approximately $41 \% \mathrm{Cu}_{3} \mathrm{~N}$ and $59 \% \mathrm{Cu}\left(\mathrm{NH}_{3}\right) \mathrm{Cl}$. IR measurements supported this analysis, with spectra clearly demonstrating the presence of $\mathrm{N}-\mathrm{H}$ stretching and bending bands from the copper(I) monoamine phase at $3295,3241 \mathrm{~cm}^{-1}\left(v_{\mathrm{as}} \mathrm{NH}\right), 3160 \mathrm{~cm}^{-1}\left(v_{\mathrm{s}} \mathrm{NH}\right)$, $1594 \mathrm{~cm}^{-1}\left(\delta_{\mathrm{a}}\left(\mathrm{NH}_{3}\right)\right)$ and $1240 \mathrm{~cm}^{-1}\left(\delta_{\mathrm{s}}\left(\mathrm{NH}_{3}\right)\right)$ [60]. The presence of copper nitride was also confirmed by a broad IR band at $664 \mathrm{~cm}^{-1}$ [61].

\subsection{Characterization and Ammonolysis Reaction of Copper(II) Oxide and Copper(II) Hydroxide Nanoparticles}

As shown in the scheme in Figure 1, the reaction of $\mathrm{Cu}_{2}(\mathrm{OH})_{3} \mathrm{Cl}$ with $\mathrm{NaOH}$ resulted in copper(II) oxide, which was obtained as a fine black powder product. The further addition of $\mathrm{NH}_{3}(a q)$ led to the transformation of the initial fine powder to the nanoneedles or star-like particles of $\mathrm{Cu}(\mathrm{OH})_{2}$ (Figure $4 \mathrm{a}-\mathrm{c}$ ), depending on the reaction conditions. The identities of the synthesized $\mathrm{CuO}$ (see Figure $4 \mathrm{~d}$ ) and $\mathrm{Cu}(\mathrm{OH})_{2}$ powders were confirmed by PXD; all the diffraction peaks in the patterns could be assigned to either $\mathrm{CuO}$ (ICDD PDF card No. 05-0661) or $\mathrm{Cu}(\mathrm{OH})_{2}$ (ICDD PDF card No. 72-0140), respectively, and no impurity peaks were observed in either case. A mechanism for the conversion of copper(II) chloride in $0.01 \mathrm{M} \mathrm{NaOH}$ has been previously suggested in the literature [62]. SEM analysis 
in this previous case indicated an initial "etching" of the crystals of the starting material in the basic solution. The growth of needle-like structures on the crystalline surface was observed as the etching continued. The previous authors assumed a mechanism in which $\mathrm{NaOH}$ reacts with $\mathrm{Cu}_{2}(\mathrm{OH})_{3} \mathrm{Cl}$ crystals and $\mathrm{Cl}^{-}$is replaced at the interface with $\mathrm{OH}^{-}$(Equation (3)). Strong deformations of the internal bulk structures occur as a result. Copper(II) hydroxide is known to form needle-like crystals in aqueous solution and "sisal-like" structures subsequently grow along the radical direction.

$$
\mathrm{Cu}_{2}(\mathrm{OH})_{3} \mathrm{Cl}+\mathrm{OH}^{-} \rightarrow 2 \mathrm{Cu}(\mathrm{OH})_{2}+\mathrm{Cl}^{-}
$$
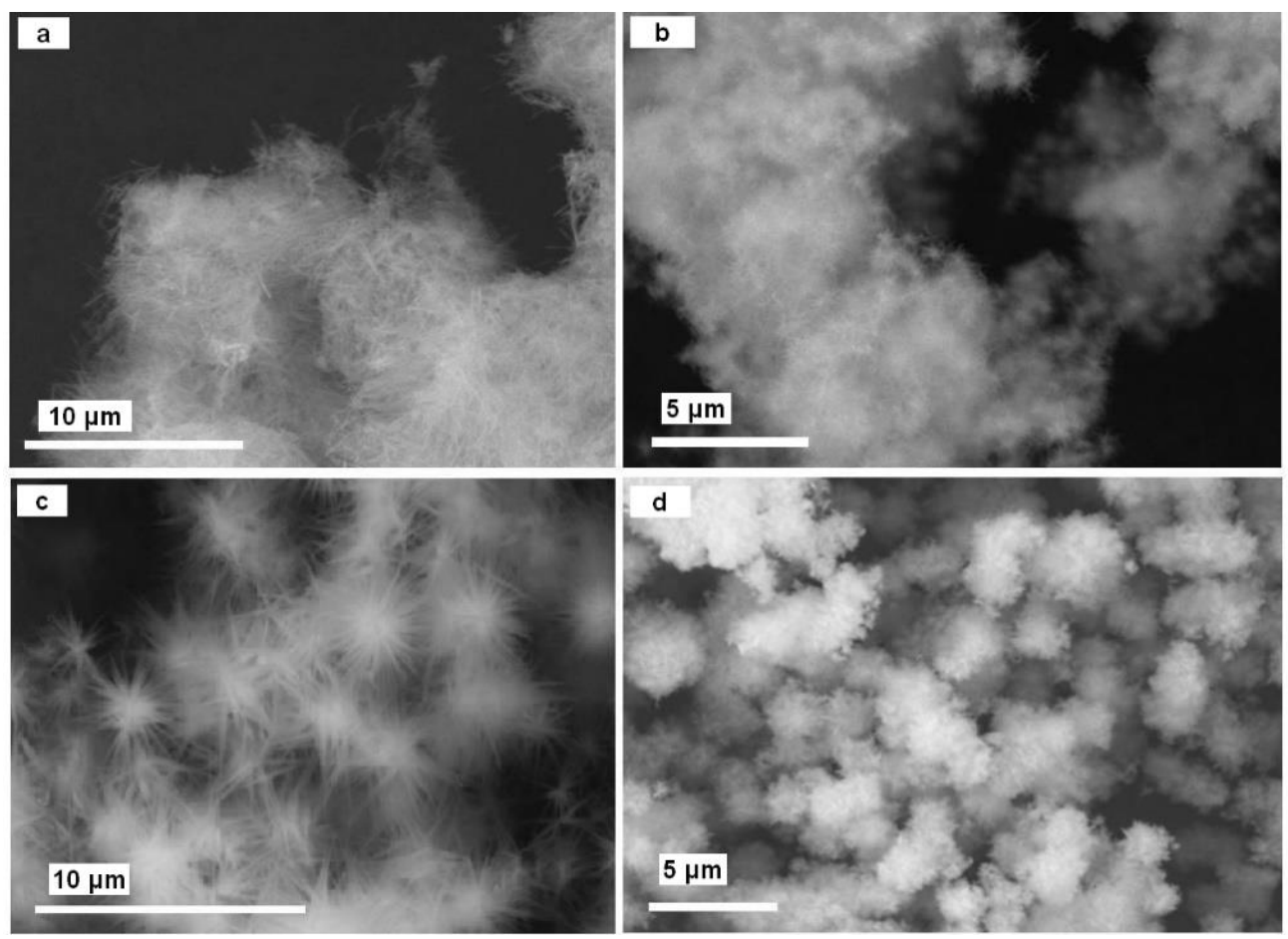

Figure 4. SEM images of powders: obtained by $\mathrm{NaOH} / \mathrm{NH}_{3}(a q)$ treatment of the $\mathrm{Cu}_{2}(\mathrm{OH})_{3} \mathrm{Cl}$ (sample A) $(\mathbf{a}, \mathbf{b})$ and $\mathrm{Cu}_{2}(\mathrm{OH})_{3} \mathrm{Cl}$ (sample B) (c) powders; obtained by $\mathrm{NaOH}$ treatment of the $\mathrm{Cu}_{2}(\mathrm{OH})_{3} \mathrm{Cl}$ (sample B) powder $(\mathbf{d})$.

In previous studies, $\mathrm{CuO}$ formation was realized by thermal treatment of the hydroxide. In our experiment copper(II) oxide occurred directly in solution, probably due to the synergistic effect of using ethanol as a solvent combined with a concentration of $\mathrm{NaOH}$ ten times less (influencing the $\mathrm{pH}$ accordingly) [63]. The solubility of $\mathrm{CO}(\mathrm{OH})_{2}$ and $\mathrm{CuO}$ in the ethanol-water system should also be considered and in the case of aqueous solutions, this difference is relatively large; the solubility of $\mathrm{Cu}(\mathrm{OH})_{2}=1.3 \times 10^{-5} \mathrm{~mol} \mathrm{~L}^{-1}$ as compared to $2 \times 10^{-7} \mathrm{~mol} \mathrm{~L}^{-1}$ for $\mathrm{CuO}$ [64].

The oxide and hydroxide samples were then heated under gaseous ammonia and the ensuing products were characterized by PXD (Figure 5), SEM (Figure 6) and BET. According to these experiments, the optimal conditions for the synthesis of phase-pure copper nitride are to use a temperature of $300{ }^{\circ} \mathrm{C}$ and a heating time of $300 \mathrm{~min}$ (Table 1).

Perhaps surprisingly, some experiments resulted in three-phase compositions (e.g., sample 4$)$, with the presence of all three common copper oxidation states $(+2,+1$ and 0 ; resulting from dehydration, nitridation and complete reduction, respectively). It is interesting to note that applying the selected precursors under the prescribed conditions led to pseudomorphic transformations from each precursor to copper nitride (Figure 6a,b). 

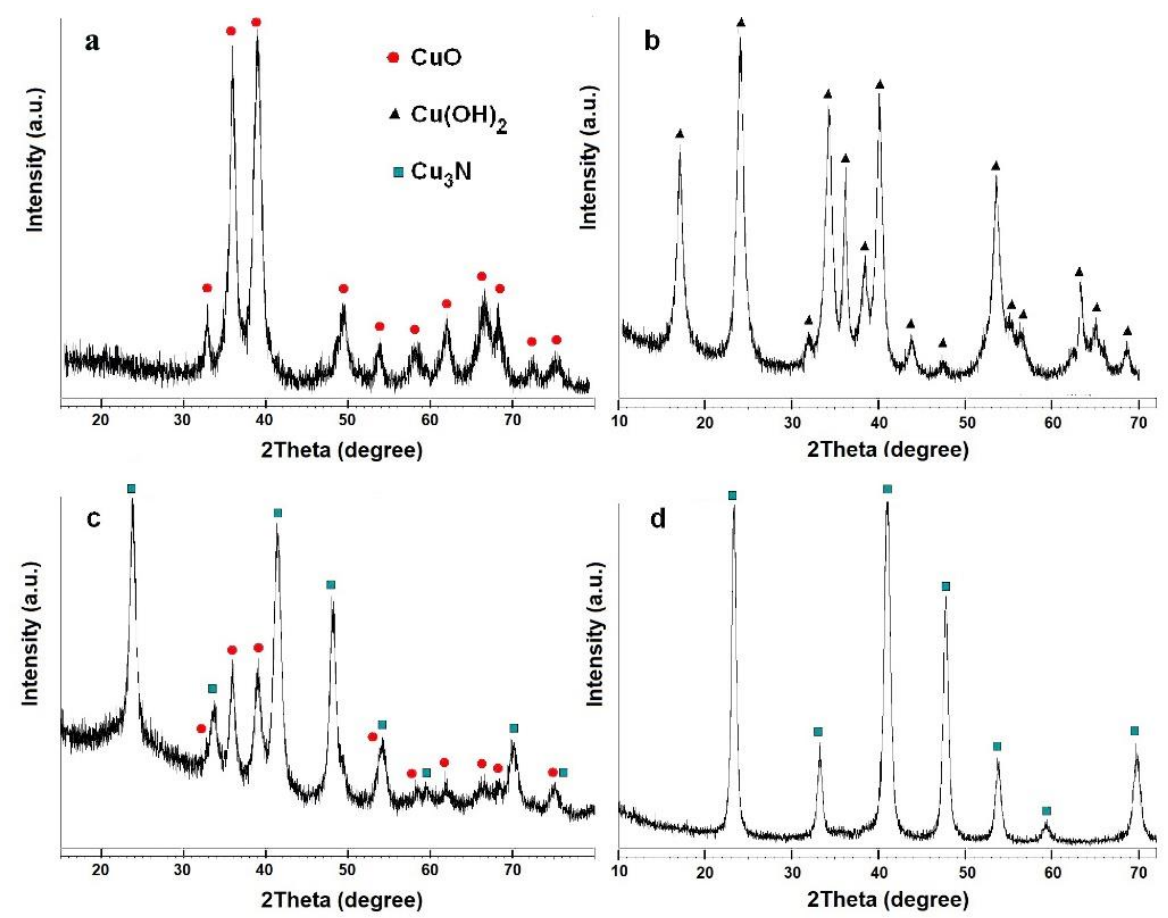

Figure 5. X-ray diffraction patterns of: $(\mathbf{a}) \mathrm{CuO},(\mathbf{b}) \mathrm{Cu}(\mathrm{OH})_{2}$ powders as-made and (c) $\mathrm{CuO}(\mathbf{2 a})$, (d) $\mathrm{Cu}(\mathrm{OH})_{2}(3 \mathbf{b})$ following ammonolysis. Red circles indicate $\mathrm{CuO}$, black triangles indicate $\mathrm{Cu}(\mathrm{OH})_{2}$ and black squares represent $\mathrm{Cu}_{3} \mathrm{~N}$.

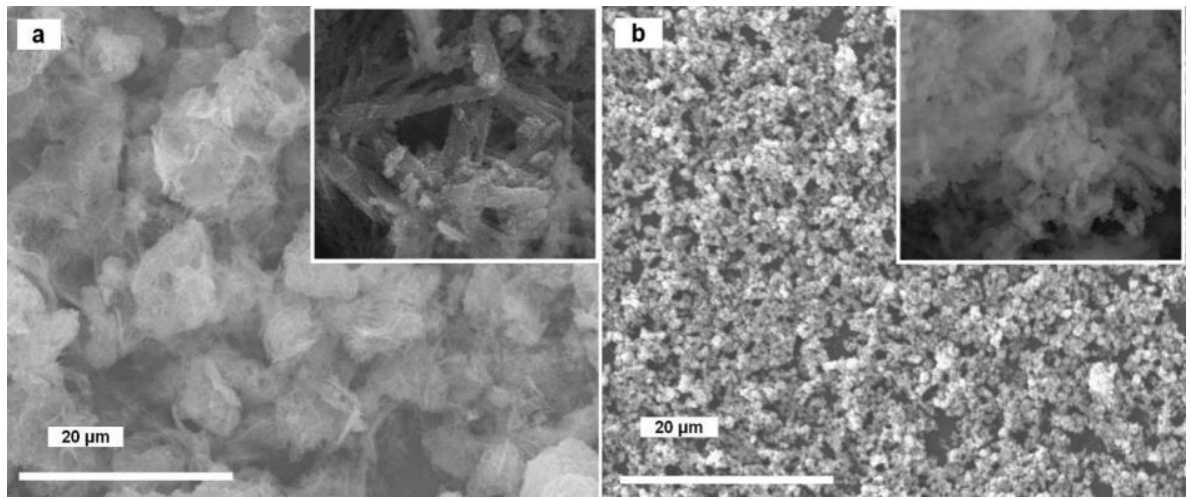

Figure 6. SEM images of as-prepared $\mathrm{Cu}_{3} \mathrm{~N}$ powders: (a) sample (2b) $(\mathrm{CuO})$ and (b) sample $(3 \mathbf{b})\left(\mathrm{Cu}(\mathrm{OH})_{2}\right)$ after ammonolysis $\left(4 \mathrm{~h}, 300{ }^{\circ} \mathrm{C}\right)$. The inset shows a view of the samples magnified $150,000 \times$.

Nitrogen adsorption-desorption experiments performed on different copper nitride samples commonly yield type II isotherms, which are typical for nonporous solids [65]. These adsorption isotherms are essentially linear in the range of $\mathrm{P} / \mathrm{P}_{\mathrm{O}}=0-0.7$ and condensation adsorption emerges in the region starting from $\mathrm{P} / \mathrm{P}_{\mathrm{o}} \sim 0.8$ to 1.0. The specific surface area for the samples obtained from the $\mathrm{Cu}(\mathrm{OH})_{2}$ precursor shows a value of approximately $45 \mathrm{~m}^{2} \mathrm{~g}^{-1}$.

The total pore volume, however, was observed to be as low as $\sim 0.15 \mathrm{~cm}^{3} \mathrm{~g}^{-1}$, essentially confirming that the material was nonporous. In the case of $\mathrm{Cu}_{3} \mathrm{~N}$ fabricated from a copper oxide precursor, the BET surface area is lower and is manifestly dependent on the precursor synthesis route; $\mathrm{CuO}$ powders synthesized from $\mathbf{A}$ and $\mathbf{B}$ in turn produced copper nitride materials with specific surface areas of $37 \mathrm{~m}^{2} \mathrm{~g}^{-1}$ and $4 \mathrm{~m}^{2} \mathrm{~g}^{-1}$, respectively. These materials were also nonporous. 
Table 1. Experimental conditions for samples prepared by ammonolysis reaction.

\begin{tabular}{|c|c|c|c|c|}
\hline $\begin{array}{l}\text { Sample } \\
\text { No. }\end{array}$ & Precursor & Temperature $/{ }^{\circ} \mathrm{C}$ & Time/min & $\begin{array}{l}\text { Product Phases from } \\
\text { PXD (wt \%) * }\end{array}$ \\
\hline 1a & $\mathrm{Cu}_{2}(\mathrm{OH})_{3} \mathrm{Cl}$ & 240 & 240 & $\mathrm{Cu}_{3} \mathrm{~N}(38)>\mathrm{Cu}\left(\mathrm{NH}_{3}\right) \mathrm{Cl}(62)$ \\
\hline $1 b$ & $\mathrm{Cu}_{2}(\mathrm{OH})_{3} \mathrm{Cl}$ & 300 & 240 & $\mathrm{Cu}_{3} \mathrm{~N}>\mathrm{Cu}\left(\mathrm{NH}_{3}\right) \mathrm{Cl}$ \\
\hline 1c & $\mathrm{Cu}_{2}(\mathrm{OH})_{3} \mathrm{Cl}$ & 330 & 240 & $\mathrm{Cu}_{3} \mathrm{~N}(41)>\mathrm{Cu}\left(\mathrm{NH}_{3}\right) \mathrm{Cl}(59)$ \\
\hline $2 a$ & $\mathrm{CuO}$ & 280 & 180 & $\mathrm{Cu}_{3} \mathrm{~N}(69)>\mathrm{CuO}(31)$ \\
\hline $2 b$ & $\mathrm{CuO}$ & 310 & 300 & $\mathrm{Cu}_{3} \mathrm{~N}$ \\
\hline $2 c$ & $\mathrm{CuO}$ & 330 & 240 & $\mathrm{Cu}_{3} \mathrm{~N}>\mathrm{Cu}$ \\
\hline $3 a$ & $\mathrm{Cu}(\mathrm{OH})_{2}$ & 300 & 240 & $\mathrm{Cu}_{3} \mathrm{~N}(77)>\mathrm{CuO}(23)$ \\
\hline $3 b$ & $\mathrm{Cu}(\mathrm{OH})_{2}$ & 310 & 300 & $\mathrm{Cu}_{3} \mathrm{~N}$ \\
\hline $3 c$ & $\mathrm{Cu}(\mathrm{OH})_{2}$ & 330 & 240 & $\mathrm{Cu}_{3} \mathrm{~N}>\mathrm{Cu}$ \\
\hline 4 & $\mathrm{Cu}(\mathrm{OH})_{2}$ & 310 & 300 & $\mathrm{Cu}_{3} \mathrm{~N}(55) / \mathrm{CuO}(33) / \mathrm{Cu}(12)$ \\
\hline
\end{tabular}

* Phase fractions ( $w \mathrm{t} \%$ ) were estimated using profile fitting within the PowderCell software [59]. For some samples the phase composition was not estimated due to the low peak intensity of the corresponding XRD patterns.

\subsection{Synthesis of $\mathrm{Cu}_{3} \mathrm{~N} / \mathrm{SiO}_{2}$ Composites}

Nanoparticles of binary inorganic copper compounds can provide a very interesting alternative to homogeneous copper complex catalysts for the cycloaddition of terminal alkynes and azides (such as the Huisgen 1,3-dipolar cycloaddition; HDC) and fulfil the requirements of a "click reaction" [66]. With such applications in mind, we were interested in exploring the precursor routes used here in the synthesis of supported $\mathrm{Cu}_{3} \mathrm{~N}$ nanomaterials. To this end, we utilized copper(II) chloride as a precursor for the preparation of copper nitride supported on silica, $\mathrm{Cu}_{3} \mathrm{~N} / \mathrm{SiO}_{2}$. To achieve this, we modified the $\mathrm{Cu}_{3} \mathrm{~N}$ synthesis process such that $\mathrm{Cu}_{3} \mathrm{~N} / \mathrm{SiO}_{2}$ nanocomposites could be achieved in a series of simple steps comprising: (i) silica modification; (ii) incorporation of $\mathrm{Cu}_{2}(\mathrm{OH})_{3} \mathrm{Cl}$ into silica; (iii) conversion of $\mathrm{Cu}_{2}(\mathrm{OH})_{3} \mathrm{Cl}+$ silica into a $\mathrm{Cu}(\mathrm{OH})_{2} / \mathrm{SiO}_{2}$ nanocomposite and (iv) ammonolysis of the $\mathrm{Cu}(\mathrm{OH})_{2} / \mathrm{SiO}_{2}$ precursor to yield $\mathrm{Cu}_{3} \mathrm{~N} / \mathrm{SiO}_{2}$.

The $\mathrm{Cu}(\mathrm{OH})_{2} / \mathrm{SiO}_{2}$ nanocomposites were prepared as detailed in the experimental section. Ammonolysis reactions using the $\mathrm{Cu}(\mathrm{OH})_{2} / \mathrm{SiO}_{2}$ precursor were performed at 250,300 and $310^{\circ} \mathrm{C}$ (over a period of $4-5 \mathrm{~h}$ ). After heating under gaseous $\mathrm{NH}_{3}$, the initially blue powders became either grey or light red in colour. Despite the colour change, only amorphous-appearing PXD patterns were observed for, e.g., a sample heated for $4 \mathrm{~h}$ at $250{ }^{\circ} \mathrm{C}$ (Figure 7a). This may suggest that the $\mathrm{Cu}_{3} \mathrm{~N}$ particles are of submicron dimensions and/or possess no long-range structural order, hence producing no Bragg reflections. Alternatively, the low wt.\% loading of $\mathrm{Cu}_{3} \mathrm{~N}$ particles might be constricted inside the internal porosity of the $\mathrm{SiO}_{2}$ matrix (support), rendering them undetectable in the X-ray diffraction patterns.

On ammoniating a nanocomposite sample at $310{ }^{\circ} \mathrm{C}$, PXD showed that the product was the intended $\mathrm{Cu}_{3} \mathrm{~N} / \mathrm{SiO}_{2}$ material (Figure $7 \mathrm{~b}$ ). Only two examples of $\mathrm{Cu}_{3} \mathrm{~N} / \mathrm{SiO}_{2}$ materials exist in the literature $[67,68]$. The impregnation of $\mathrm{SiO}_{2}$ by a $\mathrm{Cu}(\mathrm{II})$ salt in solution followed by deposition-precipitation is an effective way to fabricate oxidic copper-based $\mathrm{SiO}_{2}$ composites [69,70]. We have shown that such combined impregnation-depositionprecipitation approaches work equally well for nitride- $\mathrm{SiO}_{2}$ composites. Our early-stage observations are currently being followed by wider, systematic studies of the ammonolysis of supported materials, which will be reported in due course.

It is useful to consider the absorption behavior of both the silica host and the $\mathrm{Cu}_{3} \mathrm{~N} / \mathrm{SiO}_{2}$ nanocomposite and the resulting implications for the specific surface area of the materials (Figure $8 \mathrm{a}, \mathrm{b}$ ). The pristine $\mathrm{SiO}_{2}$ aerogel exhibits a total adsorption volume of $1125.054 \mathrm{~cm}^{3} \mathrm{~g}^{-1}$. Once modified (with trimethyl silyl chloride) the total adsorption of the silica dropped slightly to $1075.616 \mathrm{~cm}^{3} \mathrm{~g}^{-1}$. Although this constituted a $4.40 \%$ drop in the total sorption capacity, there was otherwise little difference in the adsorption behavior (as perceived from the nitrogen sorption isotherms) of the silica before and after treatment with trimethyl silyl chloride. There were fundamental changes in the internal porosity, however, and when considering the incremental pore volume (Figure 8b), the pore size 
distribution became narrower and sharper after the treatment (but otherwise remained in the mesoporous range).

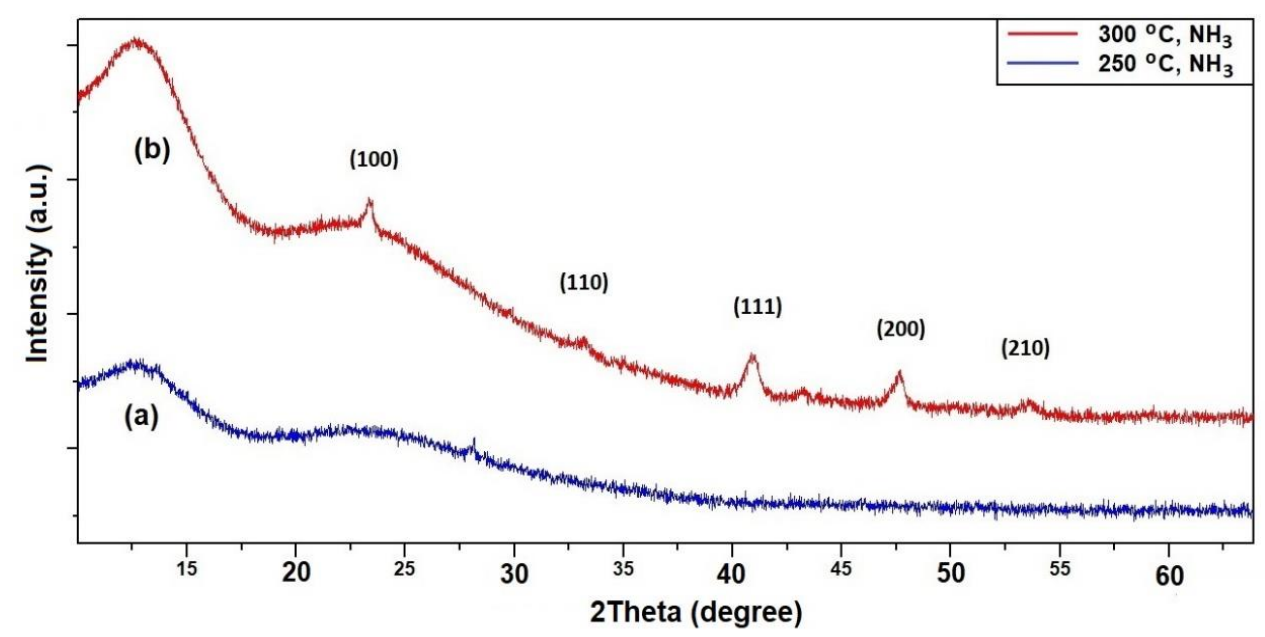

Figure 7. PXD patterns of $\mathrm{Cu}(\mathrm{OH})_{2} / \mathrm{SiO}_{2}$ composites heated under flowing $\mathrm{NH}_{3}$ gas at: (a) $250{ }^{\circ} \mathrm{C}$ (blue) and (b) $300{ }^{\circ} \mathrm{C}$ (red). The Miller indices (hkl) for copper(I) nitride, $\mathrm{Cu}_{3} \mathrm{~N}$, are indicated.

(a)

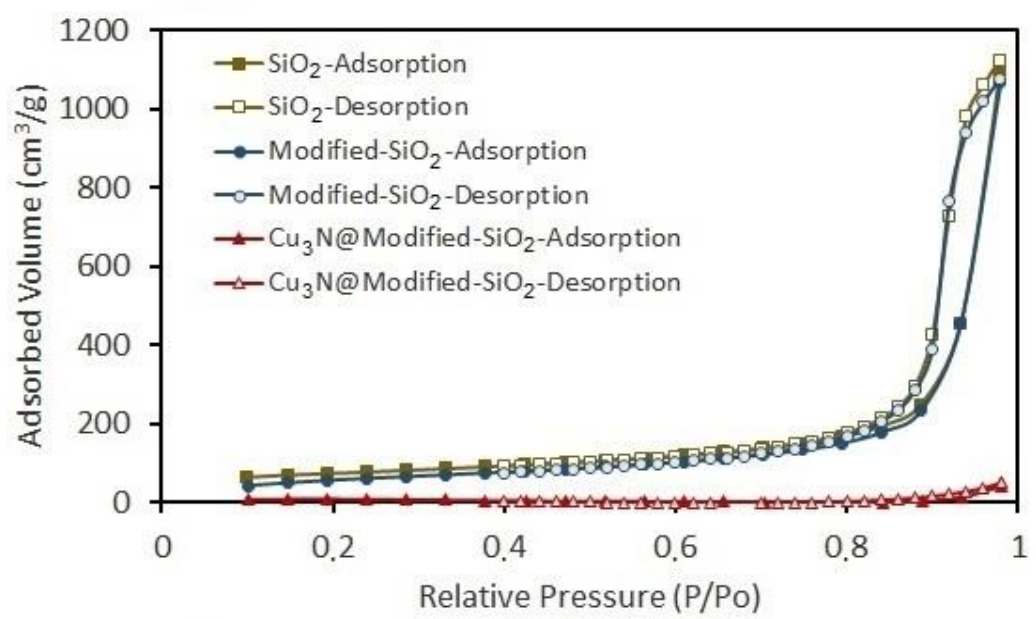

(b)

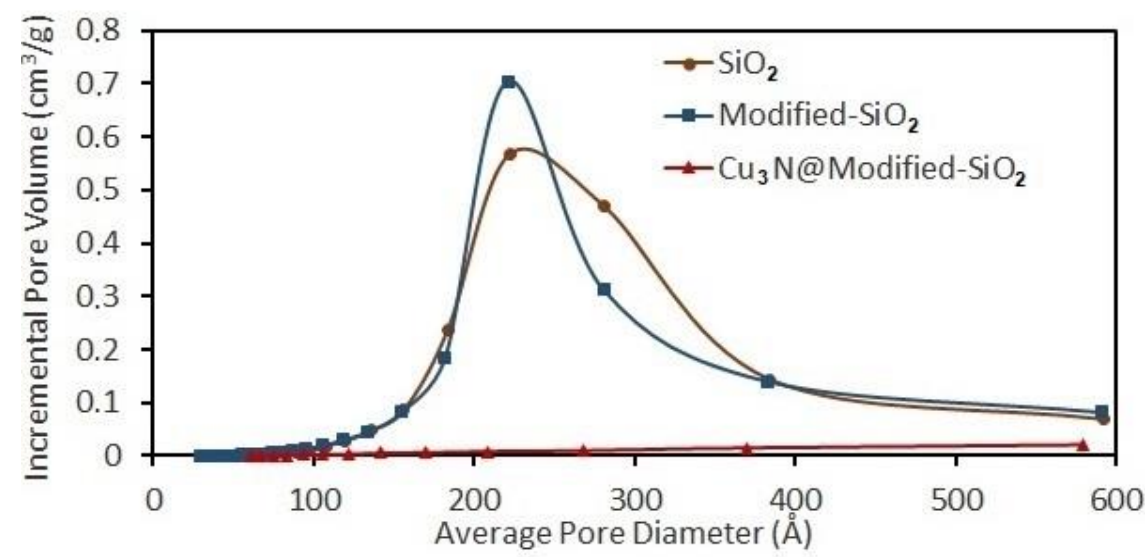

Figure 8. (a) BET isotherms and (b) the incremental pore volumes registered for the as-received $\mathrm{SiO}_{2}$ aerogel, modified $\mathrm{SiO}_{2}$ aerogel, and $\mathrm{Cu}_{3} \mathrm{~N} /$ modified $\mathrm{SiO}_{2}$ aerogel samples. 
By comparison, the $\mathrm{Cu}_{3} \mathrm{~N} / \mathrm{SiO}_{2}$ nanocomposite had a very limited nitrogen adsorption ability, with a total adsorption of $49.345 \mathrm{~cm}^{3} \mathrm{~g}^{-1}$. This constitutes a $95.41 \%$ drop in the total nitrogen sorption and hence, in relative terms, the pore volume almost disappears. This could be a reflection of the fact that the $\mathrm{Cu}_{3} \mathrm{~N}$ nanoparticles were confined within the modified- $\mathrm{SiO}_{2}$ aerogel, with uniform particle size of the same order of magnitude as the pore size of the host-approximately $21-22 \mathrm{~nm}$.

\section{Materials and Methods}

\subsection{Starting Materials}

Copper(II) chloride dihydrate, sodium hydroxide, urea, ammonium hydroxide solution $\left(25 \% \mathrm{NH}_{3}\right.$ in $\left.\mathrm{H}_{2} \mathrm{O}\right)$ and ethylene glycol (EG) were used as received (Sigma-Aldrich, St. Louis, MO, USA). The silica support material, Aerosil-200 was provided by Evonik free of charge. The silica was modified prior to use by treating with trimethyl silyl chloride (Sigma-Aldrich, St. Louis, MO, USA).

\subsection{Materials Characterization}

All products were characterized by powder X-ray diffraction (PXD) using either a Philips XPERT Pro $\theta-2 \theta$ (Malvern Panalytical Ltd., Malvern, UK) or a Bruker D8 diffractometer (Bruker AXS, Karlsruhe, Germany) with $\mathrm{CuK} \alpha$ or $\mathrm{CuK} \alpha_{1}$ radiation, respectively. Whereas PXD data for the final products were collected directly from powders, PXD data for the precursors were collected from samples dispersed in acetone dropped onto the PXD sample holder. Phase identification was performed by search-match procedures with access to the International Centre for Diffraction Data (ICDD) powder diffraction file (PDF) and by comparison to patterns generated from Inorganic Crystal Structure Database (ICSD) data using PowderCell v.2.3 [59]. Scanning electron microscopy (SEM) was performed by using three instruments: first, a Philips XL 30 environmental (E)SEM equipped with an Oxford Instruments INCA Energy 250 energy dispersive X-ray (EDX) spectrometer $(\mathrm{EHT}=20 \mathrm{kV}$, spot size 5), second, a LEO 1430 VP (LEO Electron Microscopy Ltd., Cambridge, UK) microscope equipped with a Quantax 200 (XFlash 4010 detector, Bruker AXS, Karlsruhe, Germany) EDX spectrometer (HV mode, SE, EHT $=10-20 \mathrm{kV}$, beam current $100 \mu \mathrm{A}$ ), and finally a Quanta 3D FEG instrument (FEI, Hillsboro, OR, USA) $(E H T=30 \mathrm{kV})$. The samples were imaged without coating and were placed onto carbon tabs fixed to aluminium SEM stubs. Qualitative analysis of bonding was performed by Fourier transform infrared spectroscopy (FTIR; Shimadzu 8400 S spectrometer, Shimadzu Corp., Kyoto, Japan). The surface areas of the synthesized powders were determined by applying BET analysis to nitrogen adsorption-desorption data, which were registered at liquid nitrogen temperature using a Micromeritics Gemini instrument (Norcross, GA, USA).

\section{Conclusions}

These studies demonstrate that copper nitride powders can be successfully synthesized from a range of oxygen-containing inorganic precursors. With the correct choice of experimental parameters, nitridation is favored over simple reduction. The choice of precursor and synthesis conditions enables the size and morphology of the nitride microand nanoparticles to be manipulated. Each of the precursors- $\mathrm{Cu}_{2}(\mathrm{OH})_{3} \mathrm{Cl}, \mathrm{Cu}(\mathrm{OH})_{2}$ and $\mathrm{CuO}$ - can be prepared from a copper(II) chloride starting material by urea hydrolysis in an ethylene glycol/water medium below $100^{\circ} \mathrm{C}$. The first of these precursors, $\mathrm{Cu}_{2}(\mathrm{OH})_{3} \mathrm{Cl}$, has limited utility in the preparation of $\mathrm{Cu}_{3} \mathrm{~N}$, however, since not only is the ammonolysis process not pseudomorphic (thus offering little morphology control), but it also proves challenging to prepare $\mathrm{Cu}_{3} \mathrm{~N}$ without the presence of the copper(I) monoamine, $\mathrm{Cu}\left(\mathrm{NH}_{3}\right) \mathrm{Cl}$.

Alternatively, the $\mathrm{Cu}_{2}(\mathrm{OH})_{3} \mathrm{Cl}$ precursor can be converted to $\mathrm{Cu}(\mathrm{OH})_{2}$ or $\mathrm{CuO}$ in solution by the addition of $\mathrm{NaOH} / \mathrm{NH}_{4} \mathrm{OH}$. The advantage of these solution syntheses is that $\mathrm{CuO}$ nanoparticles can be obtained quickly and without heating, retaining a similar morphology to the copper(II) chloride starting material. Similarly, nanostructured $\mathrm{Cu}(\mathrm{OH})_{2}$ can be obtained from the chloride in solution, forming as needles on the nanoscale. Both 
$\mathrm{CuO}$ and $\mathrm{Cu}(\mathrm{OH})_{2}$ precursors are successful in producing single-phase $\mathrm{Cu}_{3} \mathrm{~N}$ under a range of experimental conditions. At an elevated temperature (of ca. $330^{\circ} \mathrm{C}$ and above), the nitride seemingly decomposes, with copper metal as the predominant product. Preliminary observations suggest that mesoporous silica can act as an efficient support for $\mathrm{Cu}_{3} \mathrm{~N}$. Importantly, modification with trimethylsilyl chloride removes the hydrophilicity from the surface of $\mathrm{SiO}_{2}$ aerogel to enable successful ammoniation of $\mathrm{Cu}(\mathrm{OH})_{2} / \mathrm{SiO}_{2}$ composites. Thus, we successfully synthesized $\mathrm{Cu}_{3} \mathrm{~N} /$ modified- $\mathrm{SiO}_{2}$-aerogel nanocomposites and the hydrolysis decomposition of $\mathrm{Cu}_{3} \mathrm{~N}$ by solid-state acidic media was completely excluded.

Author Contributions: Conceptualization, R.S.; methodology, R.S., D.H.G.; investigation, R.S., T.K.A.H.; data analysis, D.H.G., R.S., T.K.A.H., L.D.; writing—original draft preparation, R.S., T.K.A.H., D.H.G., L.D.; writing—review and editing, R.S., D.H.G., L.D., T.K.A.H.; visualization, R.S., T.K.A.H., L.D.; supervision, D.H.G., R.S.; funding acquisition, D.H.G., R.S. All authors have read and agreed to the published version of the manuscript.

Funding: This research was funded by University of Glasgow, the GROWTH (WZROST) project ("Enhancing Educational Potential of Nicolaus Copernicus University in the Disciplines of Mathematical and Natural Sciences"), EPSRC grant ref. EP/I022570/1.

Institutional Review Board Statement: Not applicable.

Informed Consent Statement: Not applicable.

Data Availability Statement: Data is contained within the article.

Conflicts of Interest: The authors declare no conflict of interest. The funders had no role in the design of the study; in the collection, analyses, or interpretation of data; in the writing of the manuscript, or in the decision to publish the results.

Sample Availability: The samples are not available from the authors.

\section{References}

1. Ścigała, A.; Szłyk, E.; Dobrzańska, L.; Gregory, D.H.; Szczęsny, R. From binary to multinary copper based nitrides-Unlocking the potential of new applications. Coord. Chem. Rev. 2021, 436, 213791. [CrossRef]

2. Reichert, M.D.; White, M.A.; Thompson, M.J;; Miller, G.J.; Vela, J. Preparation and instability of nanocrystalline cuprous nitride. Inorg. Chem. 2015, 54, 6356-6362. [CrossRef] [PubMed]

3. Szczęsny, R.; Szłyk, E.; Wiśniewski, M.; Hoang, T.K.A.; Gregory, D.H. Facile preparation of copper nitride powders and nanostructured films. J. Mater. Chem. C 2016, 4, 5031-5037. [CrossRef]

4. Ji, Z; Zhang, Y.; Yuan, Y.; Wang, C. Reactive DC magnetron deposition of copper nitride films for write-once optical recording. Mater. Lett. 2006, 60, 3758-3760. [CrossRef]

5. Cremer, R.; Witthaut, M.; Neuschütz, D.; Trappe, C.; Laurenzis, M.; Winkler, O.; Kurz, H. Deposition and Characterization of Metastable Cu3N Layers for Applications in Optical Data Storage. Mikrochim. Acta 2000, 133, 299-302. [CrossRef]

6. Cui, X.Y.; Soon, A.; Phillips, A.E.; Zheng, R.K.; Liu, Z.W.; Delley, B.; Ringer, S.P.; Stampil, C. First principles study of $3 d$ transition metal doped $\mathrm{Cu}_{3}$ N. J. Magn. Magn. Mater. 2012, 324, 3138-3143. [CrossRef]

7. Yue, G.H.; Yan, P.X.; Liu, J.Z.; Wang, M.X.; Li, M.; Yuan, X.M. Copper nitride thin film prepared by reactive radio-frequency magnetron sputtering. J. Appl. Phys. 2005, 98, 103506. [CrossRef]

8. Zhao, Y.; Zhao, J.; Yang, T.; Zhang, J.; Yang, J.; Li, X. Enhanced write-once optical storage capacity of $\mathrm{Cu}_{3} \mathrm{~N}$ film by coupling with an $\mathrm{Al}_{2} \mathrm{O}_{3}$ protective layer. Ceram. Int. 2016, 42, 4486-4490. [CrossRef]

9. Hirjibehedin, C.F.; Lutz, C.P.; Heinrich, A.J. Spin coupling in engineered atomic structures. Science 2006, 312, 1021-1024. [CrossRef]

10. Navio, C.; Alvarez, J.; Capitan, M.J.; Camarero, J; Miranda, R. Thermal stability of $\mathrm{Cu}$ and Fe nitrides and their applications for writing locally spin valves. Appl. Phys. Lett. 2009, 94, 263112. [CrossRef]

11. Pereira, N.; Dupont, L.; Tarascon, J.M.; Klein, L.C.; Amatucci, G.G. Electrochemistry of $\mathrm{Cu}_{3} \mathrm{~N}$ with lithium: A complex system with parallel processes. J. Electrochem. Soc. 2003, 150, A1273-A1280. [CrossRef]

12. Xianji, L.; Hector, A.L.; Owen, J.R. Evaluation of $\mathrm{Cu}_{3} \mathrm{~N}$ and $\mathrm{CuO}$ as negative electrode materials for sodium batteries. J. Phys. Chem. C 2014, 118, 29568-29573.

13. Chen, W.; Zhang, H.; Yang, B.; $\mathrm{Li}, \mathrm{B} . ; \mathrm{Li}, \mathrm{Z}$. Characterization of $\mathrm{Cu}_{3} \mathrm{~N} / \mathrm{CuO}$ thin films derived from annealed $\mathrm{Cu}_{3} \mathrm{~N}$ for electrode application in Li-ion batteries. Thin Solid Films 2019, 672, 157-164. [CrossRef]

14. Lee, D.; Sun, S.; Kwon, J.; Park, H.; Jang, M.; Park, E.; Son, B.; Jung, Y.; Song, T.; Paik, U. Copper nitride nanowires printed Li with stable cycling for Li metal batteries in carbonate electrolytes. Adv. Mater. 2020, 32, 1905573. [CrossRef]

15. Xi, P.; Xu, Z.; Gao, D.; Chen, F.; Xue, D.; Tao, C.-L.; Chen, Z.-N. Solvothermal synthesis of magnetic copper nitride nanocubes with highly electrocatalytic reduction properties. RSC Adv. 2014, 4, 14206-14209. [CrossRef] 
16. Su, C.-Y.; Liu, B.-H.; Lin, T.-J.; Chi, Y.-M.; Kei, C.-C.; Wang, K.-W.; Perng, T.-P. Carbon nanotube-supported Cu 3 N nanocrystals as a highly active catalyst for oxygen reduction reaction. Mater. Chem. A 2015, 3, 18983-18990. [CrossRef]

17. Yin, Z.; Yu, C.; Zhao, Z.; Guo, X.; Shen, M.; Li, N.; Muzzio, M.; Li, J.; Liu, H.; Lin, H.; et al. Cu3N Nanocubes for Selective Electrochemical Reduction of $\mathrm{CO}_{2}$ to Ethylene. Nano Lett. 2019, 19, 8658-8663. [CrossRef] [PubMed]

18. Wang, Q.; Zhang, Z.; Zhao, X.; Xiao, J.; Manoj, D.; Wei, F.; Xiao, F.; Wang, H.; Wang, S. MOF-derived copper nitride/phosphide heterostructure coated by multi-doped carbon as electrocatalyst for efficient water splitting and neutral-pH hydrogen evolution reaction. ChemElectroChem 2020, 7, 289-298. [CrossRef]

19. Liang, Z.-Q.; Zhuang, T.-T.; Seifitokaldani, A.; Li, J.; Huang, C.-W.; Tan, C.-S.; Li, Y.; De Luna, P.; Dinh, C.T.; Hu, Y.; et al. Copper-on-nitride enhances the stable electrosynthesis of multi-carbon products from $\mathrm{CO}_{2}$. Nat. Commun. 2018, 9, 3828. [CrossRef]

20. Nosaka, T.; Yoshitakea, M.; Okamoto, A.; Ogawa, S.; Nakayama, Y. Thermal decomposition of copper nitride thin films and dots formation by electron beam writing. Appl. Surf. Sci. 2001, 169-170, 358-361. [CrossRef]

21. Maruyama, T.; Morishita, T. Copper nitride and tin nitride thin films for write-once optical recording media. Appl. Phys. Lett. 1996, 69, 890-891. [CrossRef]

22. Li, X.; Liu, Z.; Zuo, A.; Yuan, Z.; Yang, J.; Yao, K. Properties of Al-doped copper nitride films prepared by reactive magnetron sputtering. J. Wuhan Univ. Technol. Mater. Sci. Ed. 2007, 22, 446-449. [CrossRef]

23. Borsa, D.M.; Grachev, S.; Presura, C.; Boerma, D.O. Growth and properties of $\mathrm{Cu}_{3} \mathrm{~N}$ films and $\mathrm{Cu} 3 \mathrm{~N} / \gamma^{\prime}-\mathrm{Fe}_{4} \mathrm{~N}$ bilayers. Appl. Phys. Lett. 2002, 80, 1823-1825. [CrossRef]

24. Du, Y.; Yin, Y.; Wang, J.; Wang, Z.; Li, C.; Baunack, S.; Ma, L.; Schmidt, O.G. Nanoporous copper pattern fabricated by electron beam irradiation on $\mathrm{Cu}_{3} \mathrm{~N}$ film for SERS application. Phys. Status Solidi B 2019, 256, 1800378. [CrossRef]

25. Pierson, J.F.; Horwat, D. Addition of silver in copper nitride films deposited by reactive magnetron sputtering. Script. Mater. 2008, 58, 568-570. [CrossRef]

26. Hahn, U.; Weber, W. Electronic structure and chemical-bonding mechanism of $\mathrm{Cu}_{3} \mathrm{~N}, \mathrm{Cui}_{3} \mathrm{NPd}$, and related $\mathrm{Cu}(\mathrm{I})$ compounds. Phys. Rev. B 1996, 53, 12684-12693. [CrossRef]

27. Ding, J.-N.; Yuan, N.-Y.; Li, F.; Ding, G.-Q.; Chen, Z.G.; Chen, X.S.; Lu, W. Geometry and stability of $\mathrm{Cu}_{n} \mathrm{~N}(\mathrm{n}=1-6)$, and CunN ( $\mathrm{n}=1-5)$ clusters. J. Chem. Phys. 2009, 131, 174102. [CrossRef] [PubMed]

28. Liu, Z.Q.; Wang, W.J.; Wang, T.M.; Chao, S.; Zheng, S.K. Thermal stability of copper nitride films prepared by rf magnetron sputtering. Thin Solid Films 1998, 325, 55-59. [CrossRef]

29. Wang, J.; Chen, J.T.; Yuan, X.M.; Wu, Z.G.; Miao, B.B.; Yan, P.X. Copper nitride $\left(\mathrm{Cu}_{3} \mathrm{~N}\right)$ thin films deposited by RF magnetron sputtering. J. Cryst. Growth 2006, 286, 407-412. [CrossRef]

30. Wilczopolska, M.; Nowakowska-Langier, K.; Okrasa, S.; Skowronski, L.; Minikayev, R.; Strzelecki, G.W.; Chodun, R.; Zdunek, K. Synthesis of copper nitride layers by the pulsed magnetron sputtering method carried out under various operating conditions. Materials 2021, 14, 2694. [CrossRef]

31. Soto, G.; Díaz, J.A.; de la Cruz, W. Copper nitride films produced by reactive pulsed laser deposition. Mater. Lett. 2003, 57, 4130-4133. [CrossRef]

32. Gallardo-Vega, C.; de la Cruz, W. Study of the structure and electrical properties of the copper nitride thin films deposited by pulsed laser deposition. Appl. Surf. Sci. 2006, 252, 8001-8004. [CrossRef]

33. Juza, R.; Hahn, H. Antisomorphie von $\mathrm{Cu}_{3} \mathrm{~N}$ mit $\mathrm{ReO}_{3}$. Z. Anorg. Allg. Chem. 1939, 241, 172-178. [CrossRef]

34. Paniconi, G.; Stoeva, Z.; Doberstein, H.; Smith, R.I.; Gallagher, B.L.; Gregory, D.H. Structural chemistry of Cu ${ }_{3} \mathrm{~N}$ powders obtained by ammonolysis reactions. Sol. State Sci. 2007, 9, 907-913. [CrossRef]

35. Zachwieja, U.; Jacobs, H. Ammonothermalsynthese von kupfernitrid, Cu 3 N. J. Less-Common Met. 1990, 161, 175-184. [CrossRef]

36. Scigala, A.; Szłyk, E.; Rerek, T.; Wiśniewski, M.; Skowronski, L.; Trzcinski, M.; Szczesny, R. Copper nitride nanowire arrayscomparison of synthetic approaches. Materials 2021, 14, 603. [CrossRef]

37. Sithole, R.K.; Machogo, L.F.E.; Moloto, M.J.; Gqoba, S.S.; Mubiayi, K.P.; Van Wyk, J.; Moloto, N. One-step synthesis of Cu 3 N, $\mathrm{Cu}_{2} \mathrm{~S}$ and $\mathrm{Cu}_{9} \mathrm{~S}_{5}$ and photocatalytic degradation of methyl orange and methylene blue. J. Photochem. Photobiol. A Chem. 2020, 397, 112577. [CrossRef]

38. Choi, J.; Gillan, E.G. Solvothermal synthesis of nanocrystalline copper nitride from an energetically unstable copper azide precursor. Inorg. Chem. 2005, 44, 7385-7393. [CrossRef]

39. Wu, H.; Chen, W. Copper nitride nanocubes: Size-controlled synthesis and application as cathode catalyst in alkaline fuel cells. J. Am. Chem. Soc. 2011, 133, 15236-15239. [CrossRef] [PubMed]

40. Kadzutu-Sithole, R.; Machogo-Phao, L.F.E.; Kolokoto, T.; Zimuwandeyi, M.; Gqoba, S.S.; Mubiayi, K.P.; Moloto, M.J.; Van Wyk, J.; Moloto, N. Elucidating the effect of precursor decomposition time on the structural and optical properties of copper(I) nitride nanocubes. RSC Adv. 2020, 10, 34231-34246. [CrossRef]

41. Barman, D.; Paul, S.; Ghosh, S.; De, S.K. $\mathrm{Cu}_{3} \mathrm{~N}$ nanocrystals decorated with $\mathrm{Au}$ nanoparticles for photocatalytic degradation of organic dyes. ACS Appl. Nano Mater. 2019, 2, 5009-5019. [CrossRef]

42. Nakamura, T.; Hayashi, H.; Hanaoka, T.; Ebina, T. Preparation of copper nitride $\left(\mathrm{Cu}_{3} \mathrm{~N}\right)$ nanoparticles in long-chain alcohols at 130-200 ${ }^{\circ} \mathrm{C}$ and nitridation mechanism. Inorg. Chem. 2014, 53, 710-715. [CrossRef] [PubMed] 
43. Deshmukh, R.; Zeng, G.; Tervoort, E.; Staniuk, M.; Wood, D.; Niederberger, M. Ultrasmall Cu 3 N nanoparticles: SurfactantFree solution-phase synthesis, nitridation mechanism, and application for lithium storage. Chem. Mater. 2015, 27, 8282-8288. [CrossRef]

44. Mondal, S.; Raj, C.R. Copper nitride nanostructure for the electrocatalytic reduction of oxygen: Kinetics and reaction pathway. J. Phys. Chem. C 2018, 122, 18468-18475. [CrossRef]

45. Nakamura, T.; Hayashi, H.; Ebina, T. Preparation of copper nitride nanoparticles using urea as a nitrogen source in a long-chain alcohol. J. Nanoparticle Res. 2014, 16, 2699. [CrossRef]

46. Marinho, J.Z.; Romeiro, F.C.; Lemos, S.C.S.; Motta, F.V.; Riccardi, C.S.; Li, M.S.; Longo, E.; Lima, R.C. Urea-based synthesis of zinc oxide nanostructures at low temperature. J. Nanomater. 2012, 2012, 427172. [CrossRef]

47. Sreekanth, T.V.M.; Nagajyothi, P.C.; Reddy, G.R.; Shim, J.; Yoo, K. Urea assisted ceria nanocubes for efficient removal of malachite green organic dye from aqueous system. Sci. Rep. 2019, 9, 14477. [CrossRef]

48. Hai, C.; Li, S.; Zhou, Y.; Zeng, J.; Ren, X.; Li, X. Roles of ethylene glycol solvent and polymers in preparing uniformly distributed MgO nanoparticles. J. Asian Ceram. Soc. 2017, 5, 176-182. [CrossRef]

49. Gokulakrishnan, N.; Parmentier, J.; Trzpit, M.; Vonna, L.; Paillaud, J.-L.; Soulard, M. Intrusion/extrusion of water into organic grafted SBA-15 silica materials for energy storage. J. Nanosci. Nanotechnol. 2013, 13, 2847-2852. [CrossRef]

50. Capel-Sanchez, M.C.; Barrio, L.; Campos-Martin, J.M.; Fierro, J.L.G. Silylation and surface properties of chemically grafted hydrophobic silica. J. Colloid Interface Sci. 2004, 277, 146-153. [CrossRef]

51. Belyakova, L.A.; Varvarin, A.M. Surfaces properties of silica gels modified with hydrophobic groups. Colloids Surf. A Physicochem. Eng. Asp. 1999, 154, 285-294. [CrossRef]

52. Pollard, A.M.; Thomas, R.G. Synthesis and stabilities of the basic copper(II) chlorides atacamite, paratacamite and botallackite. Mineralog. Mag. 1989, 53, 557-563. [CrossRef]

53. Lee, S.C.; Park, S.-H.; Lee, S.M.; Lee, J.B.; Kim, H.J. Synthesis and $\mathrm{H}_{2}$ uptake of $\mathrm{Cu}_{2}(\mathrm{OH})_{3} \mathrm{Cl}, \mathrm{Cu}(\mathrm{OH})_{2}$ and CuO nanocrystal aggregate. Catal. Tod. 2007, 120, 358-362. [CrossRef]

54. Anthony, J.W.; Bideaux, R.A.; Bladh, K.W.; Nichols, M.C. Handbook of Mineralogy; Mineralogical Society of America: Chantilly, VA, USA. Available online: http:/ / www.handbookofmineralogy.org/ (accessed on 28 June 2021).

55. Yang, X.; Zhang, Q.; Gu, W.; Teng, F. Facile self-assembly of uniform $\mathrm{Cu}_{2} \mathrm{Cl}(\mathrm{OH})_{3}$ nanoflowers and its photo-Fenton degradation performance for dye wastewater. J. Cryst. Growth 2020, 541, 125681. [CrossRef]

56. Zhu, C.; Chen, C.; Hao, L.Y.; Hu, Y.; Chen, Z.Y. Template-free synthesis of $\mathrm{Cu}_{2} \mathrm{Cl}(\mathrm{OH})_{3}$ nanoribbons and use as sacrificial template for $\mathrm{CuO}$ nanoribbon. J. Cryst. Growth 2004, 263, 473-479. [CrossRef]

57. Jia, W.; Reitz, E.; Sun, H.; Li, B.; Zhang, H.; Lei, Y. From $\mathrm{Cu}_{2}(\mathrm{OH})_{3} \mathrm{Cl}$ to nanostructured sisal-like $\mathrm{Cu}(\mathrm{OH})_{2}$ and $\mathrm{CuO}$ : Synthesis and characterization. J. Appl. Phys. 2009, 105, 064917. [CrossRef]

58. Margraf, G.; Bats, J.W.; Bolte, M.; Lerner, H.W.; Wagner, M. One- and three-dimensional infinite arrays of $\mathrm{Cu}(\mathrm{I})$ ions exhibited by $\left[\mathrm{Cu}\left(\mathrm{NH}_{3}\right)_{2}\right] \mathrm{Br}$ and $\left[\mathrm{Cu}\left(\mathrm{NH}_{3}\right) \mathrm{Cl}\right]$ in the solid state. Chem. Commun. 2003, 956-957. [CrossRef]

59. Kraus, W.; Nolze, G. POWDER CELL-A program for the representation and manipulation of crystal structures and calculation of the resulting X-ray powder patterns. J. Appl. Cryst. 1996, 29, 301-303. [CrossRef]

60. Patil, K.C.; Secco, E.A. Metal halide ammines. II. thermal analyses, calorimetry and infrared spectra of fluoride ammines and hydrates of bivalent metals. Can. J. Chem. 1972, 50, 567-573. [CrossRef]

61. Nakamoto, K. Infrared and Raman Spectra of Inorganic and Coordination Compounds. Part B: Applications in Coordination, Organometallic, and Bioinorganic Chemistry, 6th ed.; John Wiley \& Sons, Inc.: Hoboken, NJ, USA, 2008. [CrossRef]

62. Park, S.H.; Kim, H.J. Unidirectionally aligned copper hydroxide crystalline nanorods from two-dimensional copper hydroxy nitrate. J. Am. Chem. Soc. 2004, 126, 14368-14369. [CrossRef]

63. Engelbrekt, C.; Malcho, P.; Andersen, J.; Zhang, L.; Ståhl, K.; Li, B.; Hu, J.; Zhang, J. Selective synthesis of clinoatacamite $\mathrm{Cu}_{2}(\mathrm{OH})_{3} \mathrm{Cl}$ and tenorite $\mathrm{CuO}$ nanoparticles by $\mathrm{pH}$ control. J. Nanopart. Res. 2014, 16, 2562. [CrossRef]

64. Mahmoud, B.G.; Khairy, M.; Rashwan, F.A.; Foster, C.W.; Banks, C.E. Self-assembly of porous copper oxide hierarchical nanostructures for selective determinations of glucose and ascorbic acid. RSC Adv. 2016, 6, 14474-14482. [CrossRef]

65. Gregg, S.J.; Sing, K.S.W. Adsorption, Surface Area and Porosity, 2nd ed.; Academic Press: London, UK, 1982; pp. 41-110.

66. Lee, B.S.; Yi, M.; Chu, S.Y.; Lee, J.Y.; Kwon, H.R.; Lee, K.R.; Kang, D.; Kim, W.S.; Lim, H.B.; Lee, J.; et al. Copper nitridenanoparticles supported on a superparamagnetic mesoporous microsphere for toxic-free click chemistry. Chem. Commun. 2010, 46, 3935-3937. [CrossRef] [PubMed]

67. Deshmukh, R.; Schubert, U. Synthesis of $\mathrm{CuO}$ and $\mathrm{Cu}_{3} \mathrm{~N}$ nanoparticles in and on hollow silica spheres. Eur. J. Inorg. Chem. 2013, 2498-2504. [CrossRef] [PubMed]

68. Zervos, M.; Othonos, A.; Sergides, M.; Pavloudis, T.; Kioseoglou, J. Observation of the direct energy band gaps of defect-tolerant $\mathrm{Cu}_{3} \mathrm{~N}$ by ultrafast pump-probe spectroscopy. J. Phys. Chem. C 2020, 124, 3459-3469. [CrossRef]

69. Li, H.; Ban, L.; Wang, Z.; Meng, P.; Zhang, Y.; Wu, R.; Zhao, Y. Regulation of $\mathrm{Cu}$ species in $\mathrm{CuO} / \mathrm{SiO}_{2}$ and its structural evolution in ethynylation reaction. Nanomaterials 2019, 9, 842. [CrossRef]

70. Kim, S.; Kang, S.W.; Kim, A.; Yusuf, M.; Park, J.C.; Park, K.H. A highly efficient nano-sized $\mathrm{Cu}_{2} \mathrm{O} / \mathrm{SiO}_{2}$ egg-shell catalyst for C-C coupling reactions. RSC Adv. 2018, 8, 6200-6205. [CrossRef] 